\title{
MANAGEMENT OF END-OF-LIFE ELECTRICAL AND ELECTRONIC PRODUCTS: THE CHALLENGES AND THE POTENTIAL SOLUTIONS FOR MANAGEMENT ENHANCEMENT IN DEVELOPING COUNTRIES CONTEXT
}

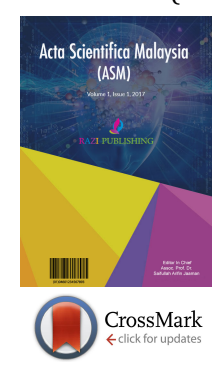

\author{
Haikal Ismaila,b, ${ }^{,}$, Marlia M.Hanafiah $^{\mathrm{a}}$ \\ ${ }^{a}$ School of Environmental and Natural Resource Sciences, Faculty of Science and Technology, Universiti Kebangsaan Malaysia, \\ 43600 UKM Bangi, Selangor, Malaysia \\ ${ }^{b}$ School of Technology Management and Logistics, College of Business, Universiti Utara Malaysia, 06010 Sintok, Kedah, Malaysia \\ *Corresponding Author: haikal@uum.edu.my
}

This is an open access article distributed under the Creative Commons Attribution License, which permits unrestricted use, distribution, and reproduction in any medium, provided the original work is properly cited.

\section{ARTICLE DETAILS}

\section{Article history:}

Received 19 October 2017

Accepted 19 October 2017

Available online 25 October 2017

\section{Keywords:}

Life Cycle Assessment (LCA);

Information and communication

technology; E-Waste Management; WEEE Management

\begin{abstract}
The accelerating disposal rate of electrical and electronic products made the research on management of end-of-life electrical and electronic products becoming an emerging research in recent years. For developed countries, several regulations and policies were designed and introduced to improve the management of end-of-life electrical and electronic products. In contrast, in developing countries they are still lacking on the implementation of such regulations and policies. Moreover, the challenges on management of end-of life electrical and electronic products faced by developing countries are differed to developed countries. Therefore, this paper aimed to provide a recommendation to improve the management of end-of-life electrical and electronic products in developing countries. To achieve the objective, this study provides an overview on the challenges faced by developing countries in management of end-of-life electrical and electronic products, followed by the suggestions on Life Cycle Assessment (LCA) as an alternative mechanism to improve current management practices for end-of-life electrical and electronic products in developing countries. The challenges to apply LCA on current management practices in developing countries were discussed and future recommendation to enhance the management of end-of-life electrical and electronic products through well-established life cycle assessment (LCA) were made.
\end{abstract}

\section{INTRODUCTION}

The rapid economic growth, shorter product life span, and technological advancement to produce affordable innovative products are among the reasons behind the increasing consumption of electrical and electronic products around the world. Consequently, the topic on managing the end-oflife of electrical and electronic products has become important topic around the world in recent years. It is because the management of end-of-life electrical and electronic products required proper disposal methods since they are differing chemically and physically with other forms of wastes (e.g. contained hazardous substances) [1]. Failure to manage them properly will damage the environment and consequently have significant impact to human health.

In general, the waste management hierarchy is a concept that was developed and used as a basic principle to guide and develop waste management strategies. The concept outlines several options to guide waste management hierarchically, from the most preferable option that considered as the best for environment to the least. Although there are several variations of forms, one of the waste management hierarchy concept was introduced by European Union under the Waste Framework Directive (Directive 2008/98/EC) served as a guideline for waste management strategy and described 'prevention' as the most preferable option for waste management followed by 'preparing for re-use', 'recycling', 'recovery' and the least option was 'disposal' (Figure 1) [2].

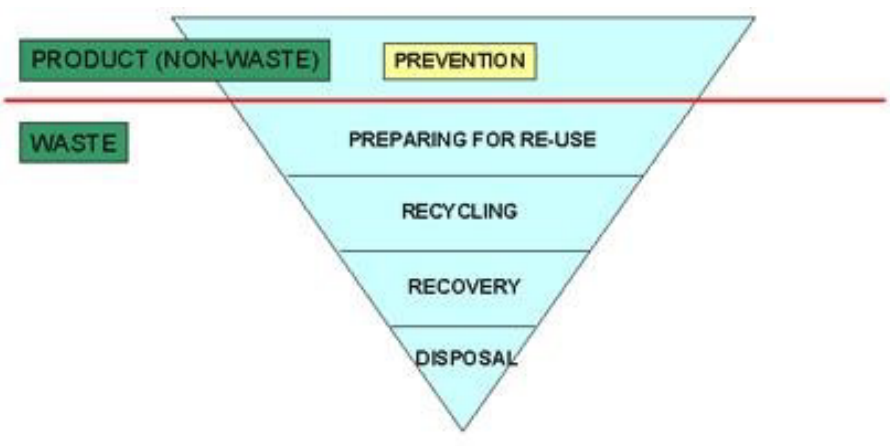

Figure 1: The Waste Management Hierarchy by European Union [3]

Like other form of waste streams, the management of end-of-life electrical and electronic products was influenced by the waste management hierarchy concept, where several regulations and policies were designed and implemented in order to promote better end-of-life electrical and electronic management.

Since 'prevention' was described as the most preferable option for waste management, the Restricting the Use of Hazardous Substances (RoHS) Directive (Directive 2002/95/EC) was designed and implemented in the European Countries that worked as 'preventive strategies' for better endof-life electrical and electronic management. The RoHS Directive has been entered into force since 2003 aims to forbid the use of several hazardous substances exceeding agreed level in new electrical and electronic product for EU market by demanding the manufacturers to use substitute and/or safer alternative materials [4].

Apart from that, the Waste Electrical and Electronic Equipment (WEEE) Directive (WEEE Directive 2002/96/EC) is another regulation that was introduced and implemented in European Countries to improve the management of waste from electrical and electronic products. The WEEE Directive has been entered into force since 2003 by demanding the manufacturers and the distributors to collect their products from consumers and dispose them properly [4]. This Directive, at the same time, promote another management options for end-of-life electrical and electronic products (i.e. re-use, recycle, recovery) by avoiding them being landfill.

Alongside with these regulations, there are several policies and tools have been developed in order to improve the management of end-of-life electrical and electronic products. The Extended Producer Responsibilities (EPR) policy is a policy based on the Polluter Pays Principle (PPP) that was designed and introduced in European Countries by demanding the manufacturers and the distributors to bear the responsibilities to take care of the products at their end-of-life stage - physically and financially [5]. Additionally, the environmental tool such as life cycle assessment (LCA), material flow analysis (MFA), substance flow analysis (SFA), multi criteria analysis (MCA), etc. were introduced and applied to improve the management of end-of-life electrical and electronic products [6].

Unlike in developed countries, where several regulations and policies were designed and implemented to improve the management of end-of-life electrical and electronic products, in developing countries they are still lacking on the implementation of such regulations and policies. Moreover, the challenges on management of end-of-life electrical and electronic products faced by developing countries are differed to developed countries 
has been provided. The challenges to apply LCA on current management practices in developing countries were discussed and future recommendation to enhance the management of end-of-life electrical and electronic products through well-established life cycle assessment (LCA) were made.

\section{MANAGEMENT OF END-OF-LIFE ELECTRICAL AND ELECTRONIC PRODUCTS IN DEVELOPING COUNTRIES}

In developed countries, several regulations and policies were implemented to improve the management of end-of-life electrical and electronic products. It is because the booming product ownership and shorter product life span in highly saturated market for electrical and electronic products in developed countries has resulted in the increasing amount of waste generated year by year. However, the amount of waste generated through the consumption of electrical and electronic products for some developing countries is not a major concern [6]. It is because the consumption rate of electrical and electronic products in developing countries is still relatively low. Moreover, due to financial constraints in developing countries, majority of the life span of the electrical and electronic products is quite longer and therefore, the amount of waste generated is smaller compared to developed countries [6].

For developing countries, the major concern on the management of end-oflife electrical and electronic products is caused by the increasing importation of electrical and electronic waste from developed countries [6]. Although the Basel Convention prohibits transboundary movement of the waste of electrical and electronic products [7,8], the imported waste from developed countries into developing countries is still occurring around the globe and it is increasing year by year, by legal or illegal operations [1]. In addition, due to lack of regulations and policies enforcement regarding to management of electrical and electronic products waste in developing countries, electrical and electronic products waste are recycled through informal recycling that neglect the environment and human health [6].

Although the electrical and electronic products waste contained several hazardous substances that become a source of environmental problem, they also provide an economic benefit as they contained several precious metals [9]. However, the lacking on regulations and policies enforcement and the increasing number of imported waste electrical and electronic products from developed countries has resulted in the evolvement of the informal recycling sector in developing countries in recent year, where the majority of precious metals from electrical and electronic products waste were recovered through primitive recycling technique [6]. As the results, reports on environmental impact and human health caused by informal recycling sector in developing countries have increased in recent years $[1,6,7]$.

\section{LCA APPLICATION ON ELECTRICAL AND ELECTRONIC PRODUCTS AND THEIR END-OF-LIFE MANAGEMENT OPTIONS}

Life cycle assessment (LCA) is an internationally standardized methodology based on ISO 14040 (ISO 2006a) and ISO 14044 (ISO 2006b), where it consists of four phases: (1) goal and scope definition, life cycle inventory, (3) life cycle impact assessment, and (4) life cycle interpretation (Figure 2). LCA has been developed as a tool to assess environmental impact of product, including their processes.

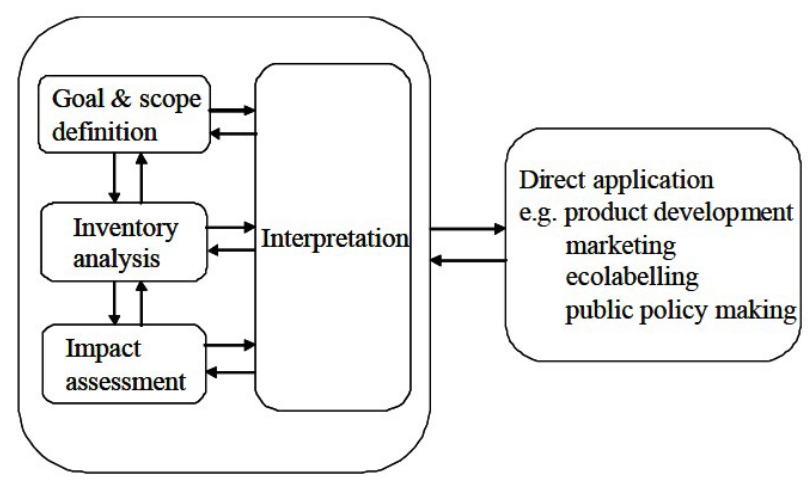

Figure 2: Life Cycle Assessment Methodology [10]

The application of LCA on electrical and electronic products has increased in recent years. They were applied widely from a large household appliance such refrigerators [11] and washing machine [12] to IT and telecommunications equipment such as personal computers [13], including intermediate products such as semiconductors [14], either to assess the entire life cycle of product or specifically on certain stage of product life cycle (e.g. end-of-life of product). Table 1 illustrates previous LCA studies on electrical and electronic products (i.e. personal computers) using the using the LCA framework by considering several end-of-life management options that include re-use, recycling, landfill and direct disposal.

Theoretically, LCA is used to evaluate the entire life cycle of product including their processes; however, it also has been used to evaluate certain stage of product life cycle (e.g. product's end-of-life stage). According to some research, LCA is used widely to assess environmental impact on management of end-of-life electrical and electronic products [6]. Moreover, a researcher has recommended that LCA is the most suitable tool to assess environmental impact of waste management and to compare environmental performance of alternative waste management [15].

\section{CURRENT LCA APPLICATION ON MANAGEMENT OF END-OF-LIFE ELECTRICAL AND ELECTRONIC PRODUCTS: THE CHALLENGES FOR DEVELOPING COUNTRIES}

The LCA application has been applied to assess environmental performance of product, either for the entire life cycle or specifically on certain stage of product's life cycle. As shown in Table 1, in previous LCA studies of personal computers, the researchers have considered several end-of-life management options and compared their implications in order to identify the best management option for better end-of-life product management. However, the information obtained from these studies may not useful for developing countries to improve their management of endof-life electrical and electronic products for several reasons.

As illustrated in Table 1, majority of LCA studies of electrical and electronic products were performed in developed countries. Although these LCA studies considered several management options to manage the end-of-life electrical and electronic products (e.g. re-use, recycling, etc.), these management options may not represent the real situation in developing countries, where the management of end-of-life electrical and electronic products is dominated by the informal recycling sectors. Moreover, the management options considered in these LCA studies were based on researchers' assumptions [16,17,18,19], scenario development [20,21] and/or based on Ecoinvent database model that represent the-state-of-theart electrical and electronic products waste management in Europe $[22,23,24]$.

Although Choi [25] and Song [13] collected specific data to represent the management of end-of-life electrical and electronic products (i.e. formal recycling) in developing countries, this information may also not applicable to majority of recycling system in developing countries dominated by informal recycling sectors [26]. It is because there are significant differences between informal recycling system and formal recycling system.

Table 1: Life Cycle Assessment of Personal Computers and their End-ofLife Management Options

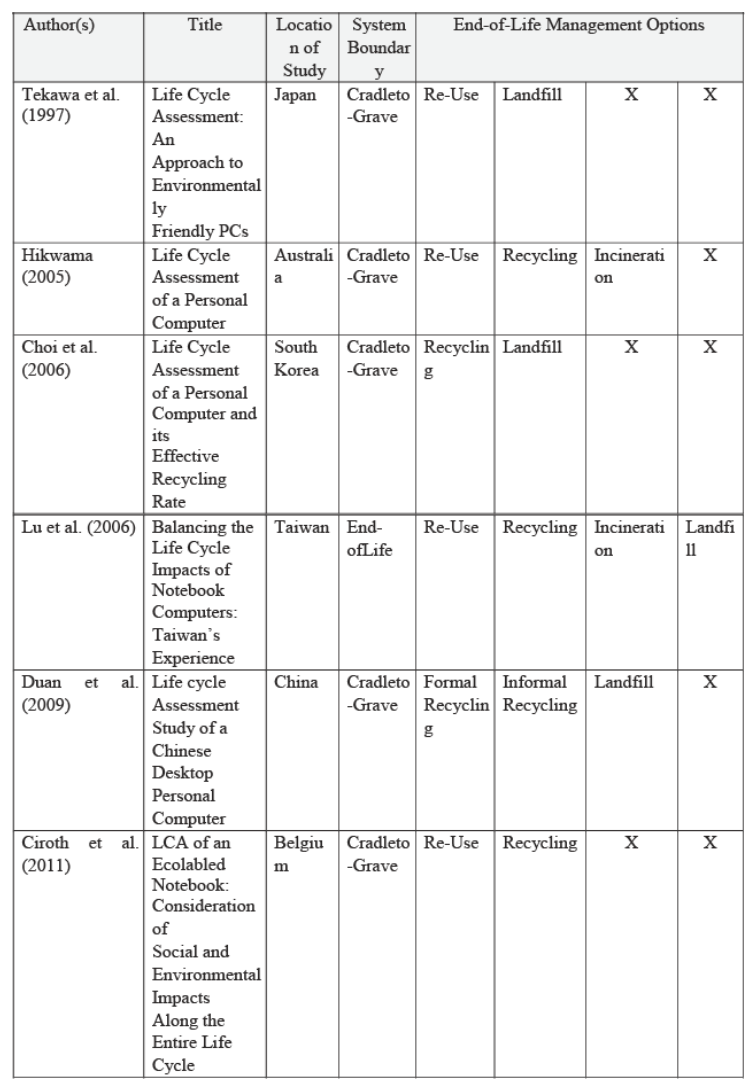




\begin{tabular}{|c|c|c|c|c|c|c|c|}
\hline $\begin{array}{l}\text { Marudut et al. } \\
\text { (2012) }\end{array}$ & $\begin{array}{l}\text { Personal } \\
\text { Computer } \\
\text { Life Cycle } \\
\text { Assessment } \\
\text { Study: The } \\
\text { Case of } \\
\text { Western } \\
\text { Australia }\end{array}$ & \begin{tabular}{|l|} 
Australi \\
a
\end{tabular} & \begin{tabular}{|l} 
Cradleto \\
-Grave
\end{tabular} & $\begin{array}{l}\text { Recyclin } \\
\mathrm{g}\end{array}$ & $\begin{array}{l}\text { Incinerati } \\
\text { on }\end{array}$ & Landfill & $\mathrm{x}$ \\
\hline $\begin{array}{l}\text { St- } \\
\text { Laurent et al. } \\
\text { (2012) }\end{array}$ & $\begin{array}{l}\text { Green } \\
\text { Electronics? } \\
\text { - An LCA } \\
\text { based Study } \\
\text { of Eco- } \\
\text { Labelling of } \\
\text { Laptop } \\
\text { Computers }\end{array}$ & Sweden & \begin{tabular}{|l} 
Cradleto \\
-Grave
\end{tabular} & $\begin{array}{l}\text { Formal } \\
\text { Recyclin } \\
\mathrm{g}\end{array}$ & Landfill & $\mathrm{x}$ & $\mathrm{X}$ \\
\hline \multirow[t]{2}{*}{$\begin{array}{l}\text { Song et al. } \\
(2013)\end{array}$} & $\begin{array}{l}\text { Life Cycle } \\
\text { Assessment }\end{array}$ & Macau & $\begin{array}{l}\text { Cradleto } \\
\text {-Grave }\end{array}$ & $\begin{array}{l}\text { Recyclin } \\
\mathrm{g}\end{array}$ & $\begin{array}{l}\text { Incinerati } \\
\text { on }\end{array}$ & $\mathrm{x}$ & $\mathrm{X}$ \\
\hline & $\begin{array}{l}\text { of Desktop } \\
\text { PCs in Macau }\end{array}$ & & & & & & \\
\hline $\begin{array}{l}\text { GrzesikWotjysi } \\
\text { ak et al. } \\
\text { (2013) }\end{array}$ & $\begin{array}{l}\text { Screening Life } \\
\text { Cycle } \\
\text { Assessment of } \\
\text { a } \\
\text { Laptop Used } \\
\text { in Poland } \\
\end{array}$ & Poland & \begin{tabular}{|l} 
Cradleto \\
-Grave
\end{tabular} & $\begin{array}{l}\text { Formal } \\
\text { Recyclin } \\
\mathrm{g}\end{array}$ & $\mathrm{X}$ & $\mathrm{x}$ & $\mathrm{X}$ \\
\hline $\begin{array}{l}\text { Hischier et al. } \\
\text { (2014) }\end{array}$ & $\begin{array}{l}\text { The Transition } \\
\text { from } \\
\text { Desktop } \\
\text { Computers to } \\
\text { Tablets: A } \\
\text { Model for }\end{array}$ & Global & $\begin{array}{l}\text { Cradleto } \\
\text {-Grave }\end{array}$ & $\begin{array}{l}\text { Formal } \\
\text { Recyclin } \\
\mathrm{g}\end{array}$ & $\mathrm{x}$ & $\mathrm{x}$ & $\mathrm{x}$ \\
\hline & $\begin{array}{l}\text { Increasing } \\
\text { Resource } \\
\text { Efficiency? }\end{array}$ & & & & & & \\
\hline
\end{tabular}

\section{DISCUSSION AND RECOMMENDATION}

The management of end-of-life electrical and electronic products in developing countries is facing serious challenges. Unlike developed countries where several regulations and policies were successfully designed and implemented to improve the management of end-of-life electrical and electronic products, majority of the developing countries still lacking on the implementation of such regulations and policies. These scenarios are even worsening owing to the increasing imported waste of electrical and electronic products from developed countries through legal and illegal operations, although there is global agreement prohibit the transboundary movement of this type of waste (i.e. the Basel Convention). As the results, the informal recycling sector for electrical and electronic products in developing countries continues to evolve in recent years and their environmental consequences have become apparent in recent scientific research. Therefore, in this paper, the authors suggest that life cycle assessment (LCA) should be considered as an alternative mechanism to improve the management of end-of-life electrical and electronic products in developing countries.

Previous LCA studies on the management of end-of-life electrical and electronic products (e.g. personal computer) have suggested that the information may not useful for developing countries to improve their management of end-of-life electrical and electronic products. It is because most of LCA studies were performed in developed countries. Therefore, they are not representing the real situation occurring in developing countries, where the management of end-of-life electrical and electronic products is dominated by the informal recycling sectors. Thus, the authors suggest that more research from developing countries that can represent real situation on informal recycling sectors are needed in order to improve current management of end-of-life electrical and electronic products in developing countries.

\section{CONCLUSIONS}

The developing countries facing different challenges on management of end-of-life electrical and electronic products compared to developed countries. The lack of regulations and policies enforcement and the increasing imported electrical and electronic products waste from developed countries have resulted in evolvement of informal recycling sector in developing countries.

For some developing countries, recycling of electrical and electronic products waste may important to them as this sector provide an economic opportunity. However, the recycling of electrical and electronic products waste in developing countries is dominated by informal recycling sector. The regulations and policies regarding to the management of electrical and electronic products in those countries are still under development, and thus LCA should be considered as an alternative mechanism to improve current management practices.

Although there are several previous LCA studies on management of endof-life electrical and electronic products, the LCA application on management of end-of-life electrical and electronic products in developing countries is still lacking, especially from informal recycling sectors. Therefore, to improve current management practices on end-of- life electrical and electronic products in developing countries, more research from developing countries by focusing on informal recycling sector are needed.

\section{ACKNOWLEDGEMENT}

Marlia Mohd Hanafiah was financed by research grants: FRGS/2/2013/ STWN01/UKM/03/1 and TD-2014012.

\section{REFERENCES}

[1] Robinson, B. H. 2009. E-waste: An assessment of global production and environmental impacts. Science of the Total Environment, 408, 183-191.

[2] European Commission. Directive 2008/98/EC on waste (Waste Framework Directive). (2016, June 9). Retrieved from http://ec.europa.eu/ environment/waste/framework/

[3] European Union. 2010. Being wise with waste: the EU's approach to waste management. Luxembourg: Publications Office of the European Union, Belgium.

[4] Ongondo, F. O., Williams, I. D., and Cherrett, T. J. 2011. How are WEEE doing? A global review of the management of electrical and electronic wastes. Waste Management, 31, 714-730.

[5] Nicol, S., and Thompson, S. 2007. Policy options to reduce consumer waste to zero: comparing product stewardship and extended producer responsibility for refrigerator waste. Waste Management Research, 25, 227-233.

[6] Kiddee, P., Naidu, R., and Wong, M. H. 2013. Electronic waste management approaches: An overview. Waste Management, 33, 12371250 .

[7] Sthiannopkao, S., and Wong, M. H. 2013. Science of the Total Environment Handling e-waste in developed and developing countries: Initiatives, practices, and consequences. Science of the Total Environment, 463-464.

[8] Widmer, R., Oswald-Krapf, H., Sinha-Khetriwal, D., Schnellmann, M., and Boni, H. 2005. Global perspectives on e-waste. Environmental Impact Assessment Review, 25, 436-458.

[9] Herat, S., and Pariatamby, A. 2012. E-waste: a problem or an opportunity? Review of issues, challenges and solutions in Asian countries. Waste Management Research, 1-17.

[10] ISO. 2006a. ISO 14040 International Standard: Environmental Management - Life Cycle Assessment - Principles and Framework.

[11] Monfared, B., Furberg, R., and Palm, B. 2014. Magnetic vs. vaporcompression household refrigerators: a preliminary comparative life cycle assessment. International Journal of Refrigeration, 42, 69-76.

[12] Park, P., Tahara, K., Jeong, I., and Lee, K. 2006. Comparison of four methods for integrating environmental and economic aspects in the end-oflife stage of a washing machine. Resources, Conservation \& Recycling, 48, $71-85$.

[13] Song, Q., Wang, Z., Li, J., and Yuan, W. 2013. Life cycle assessment of desktop PCs in Macau. International Journal Life Cycle Assessment, 18, 553-566.

[14] Andræ, A. S. G., Andersson, D. R., and Liu, J. 2005. Significance of intermediate production processes in life cycle assessment of electronic products assessed using a generic compact model. Journal of Cleaner Production, 13, 1269-1279.

[15] Finnveden, G., Björklund, A., Moberg, Å., and Ekvall, T. 2007. Environmental and economic assessment methods for waste management decision-support: possibilities and limitations. Waste Management Research, 25, 263-269.

[16] Hikwama, B. P. 2005. Life cycle assessment of personal computer. University of Southern Queensland, Toowoomba, Australia.

[17] Lu, L. T., Wernick, I. K., Hsiao, T. Y., Yu, Y. H., Yang, Y. M., and Ma, H. W. 2006. Balancing the life cycle impacts of notebook computers: Taiwan's experience. Resources, Conservation and Recycling, 48(1), 13-25.

[18] Marudut, S., Wahidul, B., and Brian, B. 2012. Personal computer life cycle assessment study: The case of Western Australia. In 10th Global 
Global Conference on Sustainable Manufacturing, 31 Oct - 2Nov 2012, Istanbul, Turkey: Middle East Technical University (pp. 277-280).

[19] Tekawa, M., Miyamoto, S., and Inaba, A. 1997. Life Cycle Assessment An Approach to Environmentally Friendly PCs. In Proceedings of the 1997 IEEE International Symposium on Electronics and Environment, San Francisco, CA, USA, 5-7 May 1997 (pp. 125-130).

[20] Ciroth, A., and Franze, J. 2011. LCA of an Ecolabeled Notebook, Consideration of Social and Environmental Impacts Along the Entire Life Cycle. GreenDeltaTC GmbH, Berlin, Germany.

[21] Duan, H., Eugster, M., Hischier, R., Streicher-Porte, M., and Li, J. 2009. Life cycle assessment study of a Chinese desktop personal computer. Science of the Total Environment, 407(5), 1755-1764.

[22] Grzesik-Wojtysiak, K., and Kuklinski, G. 2013. Screening Life Cycle
Assessment of a Laptop Used in Poland. Environment Protection Engineering, 39(3), 43-54.

[23] Hischier, R., and Wäger, P. A. 2015. The Transition from Desktop Computers to Tablets: A Model for Increasing Resource Efficiency? L.M. Hilty and B. Aebischer, Eds. ICT Innovations for Sustainability. Springer.

[24] St-laurent, I., Hedin, D., Honée, C., and Fröling, M. 2012. Green Electronics? - An LCA Based Study of Ecolabeling of Laptop Computers. In Electronics Goes Green 2012+, ECG 2012 - Joint International Conference and Exhibition, Proceedings: Berlin (Germany).

[25] Choi, B., Shin, H., Lee, S., and Hur, T. 2006. LCA Case Studies LCA Case Studies Life Cycle Assessment of a Personal Computer and its Effective Recycling Rate. Computer, 11(2), 122-128.

[26] ISO. 2006b. ISO 14044 International Standard: Environmental Management - Life Cycle Assessment - Requirements and Guidelines. 